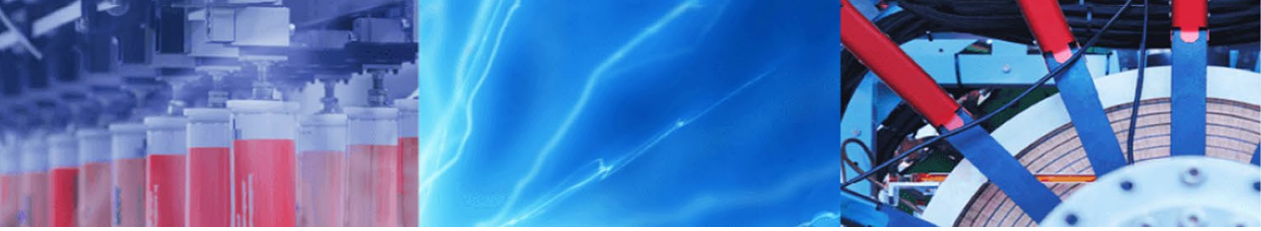

Research Article

\title{
Landfill site selection using GIS-based multi-criteria evaluation (case study: SaharKhiz Region located in Gilan Province in Iran)
}

\author{
Mojtaba Barzehkar ${ }^{1}$ (D) Naghmeh Mobarghaee Dinan ${ }^{1} \cdot$ Samaneh Mazaheri ${ }^{2} \cdot$ Rohollah Moosavi Tayebi $^{3}$. \\ Graham lan Brodie ${ }^{4}$
}

(c) Springer Nature Switzerland AG 2019

\begin{abstract}
Recognizing potential sites for landfill has increasingly become an important waste management strategy around the world. This study aims to determine municipal solid waste (MSW) landfills in SaharKhiz Region located in Gilan by comparing Fuzzy logic and Boolean logic. Fuzzy logic, which has been used in this research, is based on weighted linear combination (WLC); however, the utilized Boolean logic is considered only to determine the accuracy and validity of every method. At first, the Boolean logic using a geographical information system (GIS) is used to recognize potential and excluded zones, based on zero and one value system. In the next phase, Fuzzy logic is used, between zero and one, to standardize information layers, based on their type (increasing or decreasing). The final weight of every layer was determined using the analytical hierarchy process. Finally, the WLC method was used to integrate layers in the GIS environment to provide the final site suitability map in five classes of Fuzzy membership degree. The results show that Fuzzy logic, based on WLC, has more flexibility to resolve conflicts of human judgment, and it also has higher accuracy than Boolean logic in the selection of optimal landfill sites for MSW in SaharKhiz Region, Gilan Province, based on ecological and socioeconomic parameters.
\end{abstract}

Keywords Site selection · Municipal solid waste (MSW) · Boolean logic · Fuzzy logic · Analytical hierarchy process (AHP) · Geographical information system (GIS)

\section{Abbreviations}

AHP Analytical hierarchy process

ANP Analytical network process

EC Expert choice

EPA Environmental Protection Agency

GIS Geographical information system

IDOE Iran's Department of Environment

MSW Municipal solid waste

MCDM Multi-criteria decision making

MCE Multi-criteria evaluation

MSWDSs Municipal solid waste disposal sites

OWA Ordered weighted averaging

SDSS Spatial decision support system
TOPSIS Technique for Order Preference by Similarity to Ideal Solution

WLC Weighted linear combination

WOM Weighted overlay method

\section{Introduction}

Nowadays, population growth, along with increasing municipal solid waste (MSW) production, plays a remarkable role in environmental pollution. MSW management, to recognize suitable landfill sites, is an indispensable step of environmental planning, where the selection of a landfill

Mojtaba Barzehkar, m.barzehkar2@gmail.com; Naghmeh Mobarghaee Dinan, n_mobarghaee@sbu.ac.ir; Samaneh Mazaheri, Samaneh.mazaheri@uoit.ca; Rohollah Moosavi Tayebi, Moosavi.tayebi@gmail.com; Graham lan Brodie, grahamb@unimelb.edu.au| ${ }^{1}$ Environmental Sciences Research Institute, Shahid Beheshti University, Tehran, Iran. ${ }^{2}$ Ontario Tech University, Oshawa, Canada. ${ }^{3}$ Islamic Azad University, Tehran, Iran. ${ }^{4}$ Faculty of Agricultural Sciences, Melbourne University, Melbourne, Australia. 
site for disposal of solid waste can assure habitat conservation and promote human health [1]. More importantly, environmental challenges caused by the leakage from MSW, which can potentially contaminate groundwater and surface water resources, are one of the significant and tangible environmental impacts of a landfill site, where appropriate ecological and socioeconomic circumstances, as well as precise engineering design of landfill site, will contribute greatly to reducing leakage and protection of the environment [2]. Selection of optimal landfill sites for MSW is one of the most important principles of urban planning which can be defined as a practical method to attain sustainable urban development. To reduce its environmental impacts, locating a landfill is the basis for sound management of MSW [3]. Regarding the negative environmental impacts of waste disposal on human health and welfare, environmental experts must decide on planning for MSW landfill based on the environmental capacity of land in cooperation with relevant public agencies [4]. Often, environmental negative consequences of landfill site selection are of interest to environmental specialists and related experts; proper site selection of MSW landfill through multi-criteria decision-making (MCDM) method within the framework of ecological capacity assessment can lead to establishing a logical framework. Parameters such as slope, geological formations, soil texture, proximity to surface water, groundwater depth, land use (forest, pastures, farmlands), proximity to population centers, proximity to protected areas, distance from industrial areas, distance from power transmission lines, and distance from access roads all play an pivotal role in selection of MSW landfill [5]. Some of the mentioned parameters have more importance to locating suitable landfills than other parameters, including groundwater depth, proximity to surface water sources, soil texture, type of geological formations, distance from protected areas, and distance from population centers [6]. Geographical information system (GIS) is a useful and high-performance tool in studies pertaining to sanitary landfill site selection, as a spatial decision support system (SDSS) with a strong set of tools to enter, store, display, analyze and model spatial data as well as the ability to handle large volumes of spatial data from different sources [7]. The potential advantage of using GIS for site selection lies within the fact that using GIS not only reduces time and saves money for MSW landfill site selection, but also provides a digital database for long-term monitoring of a landfill [8].

In addition to GIS, MCDM method can be applied to solve landfill site selection problems [9]. MCDM is based on the assumption that decision-making issues should be divided into smaller comprehensible sections that can be analyzed independently, and at the end, those decisionmaking segments will be integrated in a logical manner
[9]. Integrating GIS and MCDM generates a strong problem-solving tool for spatial issues regarding the selection of MSW landfill [10]. This is because GIS analyzes spatial and descriptive criteria at the same time and turns raw data into valuable information, while MCDM, in turn, addresses ranking and prioritizing of landfill sites by considering ecological parameters [11]. Several studies have been carried out on landfill site selection for MSW in the context of multi-criteria evaluation (MCE) approaches. Osra and Kajjumba [12] applied an integration approach based on GIS and analytical hierarchy process (AHP) to demonstrate pragmatically the connections between the diverse landfill site selection factors in Makkah, Saudi Arabia. They found that this method would be an efficient method to identify the most desirable locations in Makkah [12]. Yildirim and Guler [13] used AHP, GIS, and weighted overlay method (WOM) based on weighted linear combination (WLC) for identification and selection of municipal solid waste disposal sites (MSWDSs) for the Mersin Region in the southeast of Turkey. They classified the suitability map indicating six suitability classes [13]. Torabi Kaveh et al. [14] utilized GIS-based multi-criteria evaluation (MCE) based on the AHP in terms of identifying the appropriate sites for the landfill in the Iranshahr Region. They obtained four suitability classes within the study area were identified [14]. Karimzadeh Motlagh and Sayadi [15] utilized MCDM methods based on WLC and ordered weighted averaging (OWA) and analytical network process (ANP) for the landfill site selection of the Birjand plain. Their research outcomes revealed that the OWA method, in comparison with WLC and ANP, had great potential and flexibility in the modeling of the complex decision-making problems [15]. Abd-El Monsef [16] used GIS, remote sensing, and AHP to identify and locate suitable locations for new landfill sites along coastal desert regions of the Red Sea in Egypt. They found two suitable sites for MSW landfill [16]. Ghobadi et al. [17] undertook an MSW landfill site selection, in Hamedan Province, by integrating GIS and AHP, and they classified areas based on three suitability classes [17]. In the present study, comparison of Fuzzy logic, based on WLC, and Boolean logic, in the ArCGIS 10.3 software environment, was made to select MSW landfill site in Saharkhiz Region in Gilan Province, according to the ecological and socioeconomic parameters.

\section{Study area}

The study area, SaharKhiz Region, is a part of the coastal zone of the Caspian Sea which is located in Gilan Province. Saharkhiz Region has a latitude of $37^{\circ} 19^{\prime} \mathrm{N}$ and a longitude of $50^{\circ} 13^{\prime} \mathrm{E}$, which is placed 23 to $26 \mathrm{~m}$ below sea level. The region's area is $1627.10 \mathrm{~km}^{2}$, and the slope 
of the land surface is toward the northwest. According to the field observation, the area has a few steep slopes and is mainly used for agriculture [18]. From surface water resources' point of view, there are 11 permanent rivers and 2 permanent lakes in the area, among which Sefidrood and Shamrood are the most important permanent rivers in the area. Saharkhiz Region includes cities such as Roodsar, Langerood, Lahidjan, Astaneh Ashrafie, and Kia Shahr. Consequently, the study area has a high population density. On the other hand, the important protected habitats in the area, which are rich in flora and fauna, are Boojagh National Park, Amir Kolayeh Wildlife Refuge, Safrabashte Forest Reserve, and some other valuable wetlands. Also, dangerous facilities such as gas pipelines, Kelachay Mine, and Lahidjan Car Factory are located within the studied area [18]. Figure 1 shows the location of SaharKhiz Region in Gilan Province, Iran.

\section{Methodology}

\subsection{Boolean logic}

To select the MSW landfill site in SaharKhiz Region, a large number of socioeconomic and ecological parameters are involved. After determining the ecological and socioeconomic sub-criteria in the GIS environment, a common projection coordinate system was determined for all of the layers based on the WGS 84/UTM zone $39 \mathrm{~N}$. Then, by using the Boolean logic method, the constraint criteria reflect the imposed conditions regarding decision-making options. Constraints make it possible to consider the separated spatial options from the rest of the choices; in fact, the constraints contain the criteria in which there is no feasibility for the MSW site selection and should be considered as the separated criteria, including the slopes of more than $15 \%$, areas situated inside floodplains, areas located at a distance of less than $100 \mathrm{~m}$ from active faults, areas placed in a distance of less than $1000 \mathrm{~m}$ from population centers, etc. [19]. Table 1 shows the layers and standards for landfill site selection regarding Iran's Department of Environment (IDOE) requirement.

\subsection{The Fuzzy logic approach based on WLC}

The second method which is used in this research is the Fuzzy logic approach based on WLC, one of the most popular MCDM methods, in which standardization of spatial criteria is continuous. At first, standardization of criteria raster layers was used depending on the function type (whether ascending or descending). Since the importance of landfill spatial criteria varies, it is necessary to determine the weights of criteria using AHP before implementing the
WLC method. In the following stage, questionnaires on the priority and importance of ecological and socioeconomic criteria were distributed among environmental experts [20]. One of the most common methods of spatial decision making based on GIS is applying AHP for weighting the criteria and sub-criteria. In order to determine the weight of ecological and socioeconomic criteria and sub-criteria, a pairwise comparison matrix of each element within every level was constructed. This matrix showed the importance of each element against another [17]. Next, experienced environmental experts' comments were used to determine the priorities of every two criteria undergoing pairwise comparison. Finally, the geometric mean of their survey was used as an input to the expert choice (EC) software to determine the final weight of the ecological and socioeconomic sub-criteria [17]. While the AHP process determines the weight of indicator criteria, the rate of inconsistency can be calculated, so experts will be able to make a decision about pairwise judgments. If the rate of judgment inconsistency is equal to or smaller than $10 \%(0.1)$, it will be considered acceptable; otherwise, weighting should be repeated [21]. Table 2 shows the preference values for pairwise comparison of criteria and sub-criteria [22].

Following this, each standardized factor was multiplied by the final weight obtained from AHP, and then layers were added together. The final map related to the calculated preference $0-1$ is related to the suitable areas. This method is based on Eq. (1) [23], where $S$ represents site suitability of the area, $W_{i}$ is the final weight of the criteria, $X_{i}$ is the Fuzzy value of the criteria, and $n$ represents the number of criteria [24].

$S=\sum_{i=1}^{n} w_{i} x_{i}$

To integrate the WLC method into the spatial analysis, after preparing the raster maps of the ecological and socioeconomic parameters, a suitable approach for multicriteria comparison of all the parameters needs to be considered, which is called MCE. In fact, due to the adverse essence of the ecological and socioeconomic parameters, all of the parameters should be chosen in a standard unit, in terms of being compared with each other. WLC method is one of the most fundamental approaches for standardization of data layers between the standard unit of zero and one, based on the standardization formulations for ascending and descending according to the type of data layer [25]. Table 3 shows the threshold values and Fuzzy membership function to standardize of different layers in Fuzzy logic for landfill site selection regarding IDEO requirements. Figure 2 presents several stages of MSW landfill site selection by comparing Boolean logic and Fuzzy logic based on WLC in the studied area. 

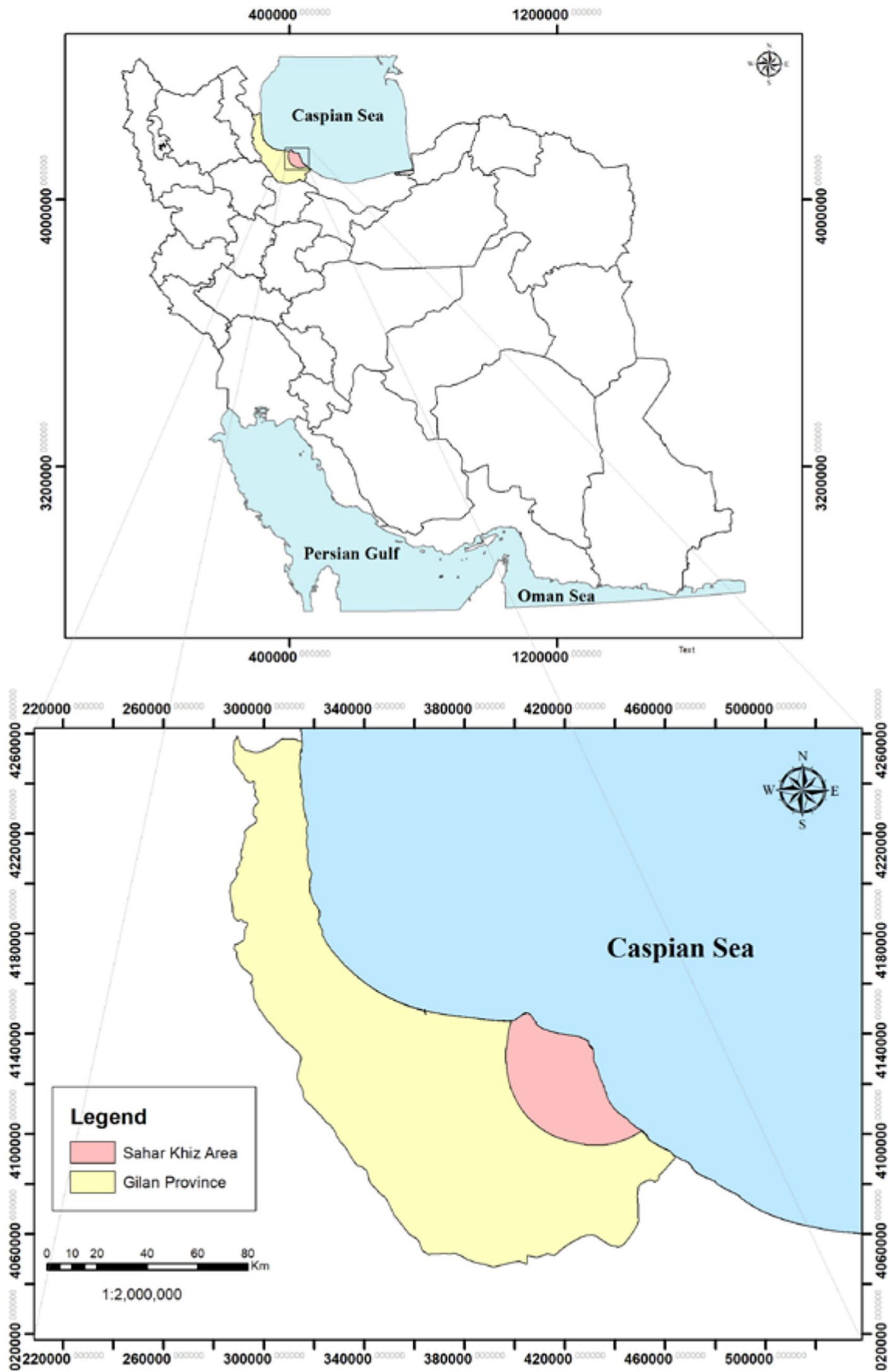

Fig. 1 Location of SaharKhiz Region in Gilan Province, Iran 
Table 1 Criteria and standards for the selection of landfill site by using Boolean logic [19]

\begin{tabular}{|c|c|c|c|}
\hline Row & Ecological and socioeconomic layers & $\begin{array}{l}\text { Acceptable standard for landfill site } \\
\text { selection }\end{array}$ & Value \\
\hline 1 & Slope (\%) & $<15 \%$ & 1 \\
\hline 2 & Distance from fault & $\geq 200 \mathrm{~m}$ & 1 \\
\hline 3 & Flooding & Areas outside the flood plain & 1 \\
\hline 4 & Groundwater depth & $\geq 10 \mathrm{~m}$ & 1 \\
\hline 5 & Distance from lake & $\geq 1000 \mathrm{~m}$ & 1 \\
\hline 6 & Distance from river & $\geq 1000 \mathrm{~m}$ & 1 \\
\hline 7 & Distance from shoreline & $\geq 1000 \mathrm{~m}$ & 1 \\
\hline 8 & Distance from protected area & $\geq 1000 \mathrm{~m}$ & 1 \\
\hline 9 & Distance from wetland & $\geq 1000 \mathrm{~m}$ & 1 \\
\hline 10 & Distance from population centers & $\geq 1000 \mathrm{~m}$ & 1 \\
\hline 11 & Distance from road & $\geq 300 \mathrm{~m}$ & 1 \\
\hline 12 & Distance from power transmission line & $\geq 100 \mathrm{~m}$ & 1 \\
\hline 13 & Distance from gas pipeline & $\geq 1000 \mathrm{~m}$ & 1 \\
\hline 14 & Distance from industrial & $\geq 1000 \mathrm{~m}$ & 1 \\
\hline
\end{tabular}

\section{Site Selection Criteria}

Table 2 The preferences values for pairwise comparison [22]

\begin{tabular}{ll}
\hline Preferences & Numerical value \\
\hline Extremely preferred & 9 \\
Very strongly preferred & 7 \\
Strongly preferred & 5 \\
Moderately preferred & 3 \\
Equally preferred & 1 \\
Moderately preferred & $1 / 3$ \\
Strongly preferred & $1 / 5$ \\
Very strongly preferred & $1 / 7$ \\
Extremely preferred & $1 / 9$ \\
Less important between the above & $1 / 8,1 / 6,1 / 4,1 / 2,8,6,4,2$ \\
intervals & \\
\hline
\end{tabular}

Generally, selecting a suitable landfill site would minimize the risk to human health as well as decrease the negative effects on the environment. Additionally, it will reduce the costs of waste disposal [26]. The selected areas for landfilling should be close to the source of waste and far from protected areas (wildlife refuges, national parks, natural monument, in addition to protected areas of Iran Department of Environment). Underground water depth in the area must be low, and access to the roads and transport routes should be facile. The area must be flat without any steep slope and far from surface water resources (rivers and lakes) or

Table 3 Threshold values and Fuzzy membership function to standardize the different layers in Fuzzy logic for landfill site selection [19]

\begin{tabular}{|c|c|c|c|c|c|}
\hline \multirow[t]{2}{*}{ Row } & \multirow[t]{2}{*}{ Ecological and socioeconomic layers } & \multicolumn{2}{|c|}{ Threshold value } & \multirow{2}{*}{$\begin{array}{l}\text { Type of the Fuzzy mem- } \\
\text { bership function }\end{array}$} & \multirow{2}{*}{$\begin{array}{l}\text { Name of the Fuzzy } \\
\text { membership func- } \\
\text { tion }\end{array}$} \\
\hline & & Control line a & Control line $b$ & & \\
\hline 1 & Slope (\%) & 15 & 5 & Decreasing & S-shape \\
\hline 2 & Distance from fault & 200 & 1000 & Increasing & S-shape \\
\hline 3 & Groundwater depth & 10 & 100 & Increasing & S-shape \\
\hline 4 & Distance from lake & 1000 & 2000 & Increasing & S-shape \\
\hline 5 & Distance from river & 1000 & 2000 & Increasing & S-shape \\
\hline 6 & Distance from shoreline & 1000 & 2000 & Increasing & S-shape \\
\hline 7 & Distance from protected area & 1000 & 2000 & Increasing & S-shape \\
\hline 8 & Distance from wetland & 1000 & 2000 & Increasing & S-shape \\
\hline 9 & Distance from population centers & 1000 & 2000 & Increasing & J-shape \\
\hline 10 & Distance from road & 1000 & 300 & Decreasing & J-shape \\
\hline 11 & Distance from power transmission line & 100 & 1000 & Increasing & S-shape \\
\hline 12 & Distance from gas pipeline & 1000 & 2000 & Increasing & S-shape \\
\hline 13 & Distance from industrial & 1000 & 2000 & Increasing & S-shape \\
\hline
\end{tabular}




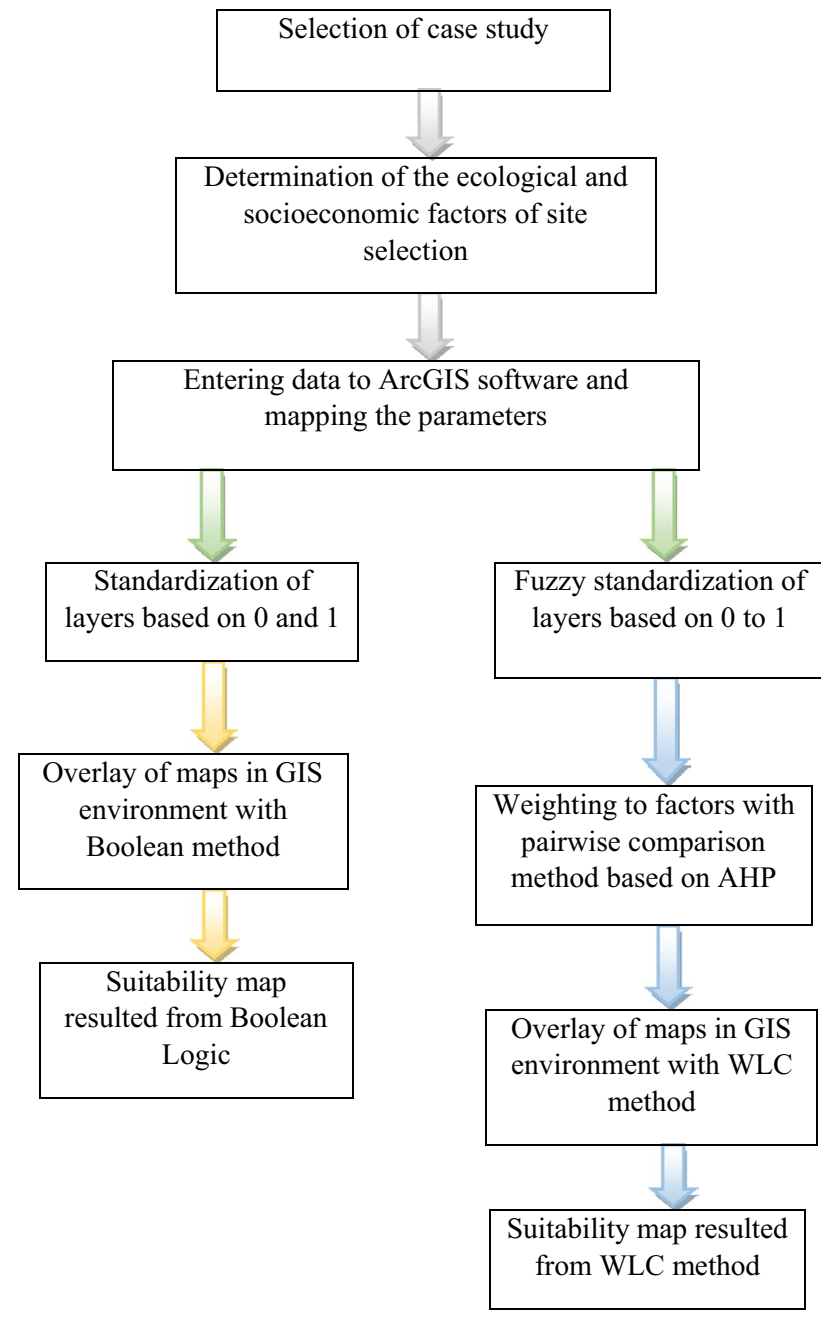

Fig. 2 Stages of MSW landfill site selection by comparing Boolean logic and Fuzzy logic based on WLC in Saharkhiz Region in Gilan Province

areas which are prone to earthquakes and faults. In fact, these areas have more capability for landfill site selection than others [27]. Table 4 shows the list and description of ecological criteria for MSW landfill site selection in SaharKhiz Region, Gilan Province. Table 5 shows the list and description of socioeconomic criteria for MSW landfill site selection in SaharKhiz Region, Gilan Province. To utilize the Fuzzy logic based on WLC, in terms of Iran's Department of Environment (IDOE), all parameters related to ecological and socioeconomic parameters were standardized between the standard unit of zero and one [28]. Parameters include slope, flood, distance from the fault, distance from protected areas, distance from wetlands, distance from lakes, distance from the coast, distance from population centers, distance from power lines, distance from the gas pipeline, and distance from roads.

\section{Results}

By using Iran's Department of Environment (IDOE) regulation for MSW landfill site selection together with environmental experts' views, which were utilized for ecological and socioeconomic sub-criteria, this study illustrated that ecological sub-criteria such as groundwater depth, distance from surface water resources, and flooding play a key role in landfill site selection. Also, among socioeconomic sub-criteria, distance from population centers (urban and rural) is an important factor for landfill site selection. As a result, if landfill site selection is done correctly and in accordance with environmental assessment (ecological and socioeconomic capacity), the urban environment will be protected, socioeconomic requirements will be met, and it will be in accordance with principles of sustainable development. After final map preparation using Boolean logic, it is shown that about 14.72\% $\left(239.53 \mathrm{~km}^{2}\right)$ of SaharKhiz Region in Gilan Province has site suitability, whereas $85.28 \%\left(1387.57 \mathrm{~km}^{2}\right)$ has unsuitable properties for landfill site selection. Also, in the final map prepared through Fuzzy logic based on WLC, it was determined that about $2.94 \%$ of Saharkhiz Region with an area of $47.83 \mathrm{~km}^{2}$ has very low site suitability; $17.31 \%$ of the region with an area of $281.73 \mathrm{~km}^{2}$ has low site suitability; $35.23 \%$ of the region with an area of $573.20 \mathrm{~km}^{2}$ has moderate site suitability; $28.65 \%$ of the region with an area of $466.23 \mathrm{~km}^{2}$ enjoys high site suitability; and $15.77 \%$ of the region with an area of $256.65 \mathrm{~km}^{2}$ is endowed with very high site suitability for MSW landfill site selection. In this study, standardization of ecological and socioeconomic sub-criteria on a continuous scale (between 0 and 1 ) is provided by employing Fuzzy logic, and as a result, the relative desirability of suitable areas for MSW landfill can be determined. Furthermore, the capacity of Fuzzy logic based on WLC in terms of allocating different relative weights to any of the ecological and socioeconomic sub-criteria in the process of information layer integration is one of the advantages of this method. Therefore, one can decide on MSW landfill site selection in SaharKhiz Region according to the region's environmental capacity (region's ecological and socioeconomic capacity).

As shown in Fig. 3, the local desirability range for MSW landfill site selection is discrete. Figure 3 represents MSW landfill site selection by applying Boolean logic in SaharKhiz Region of Gilan Province. In Fig. 4, site suitability for MSW landfill site selection in SaharKhiz Region is continuous. According to the ecological and socioeconomic parameters, unsuitable sites are scored zero and others are marked between zero and one. One of the most important differences among maps of Boolean 
Table 4 List and description of ecological criteria for landfill site selection [29-33]

\begin{tabular}{|c|c|}
\hline Ecological criterion & Description \\
\hline Slope & $\begin{array}{l}\text { The area's slope, as a key factor in the production of surface runoff, facilitates pollutant } \\
\text { transfer from the landfill into the groundwater and surface water resources. In fact, } \\
\text { lands with high slope cause more drilling costs for landfilling. According to studies } \\
\text { conducted in other countries on landfill site selection for MSW, slope values of less } \\
\text { than } 15 \% \text { are appropriate and those of more than } 15 \% \text { are unsuitable }\end{array}$ \\
\hline Flooding & $\begin{array}{l}\text { Iran's Department Of Environment (IDOE) regulations for MSW landfill site selection } \\
\text { stipulate that floodplains with a return period of } 100 \text { years are unsuitable for selec- } \\
\text { tion. Therefore, regions that are located outside the scope of floodplains are identi- } \\
\text { fied and assessed as suitable areas }\end{array}$ \\
\hline Distance from fault & $\begin{array}{l}\text { The areas located far away from active faults are suitable areas for landfilling. In fact, } \\
\text { faults increase the possibility of groundwater pollution by leachate. According to } \\
\text { the IDOE regulations, a distance of more than } 200 \mathrm{~m} \text { from active faults is suitable for } \\
\text { MSW landfill site selection }\end{array}$ \\
\hline Soil texture & $\begin{array}{l}\text { Since lower recharge rates will protect groundwater resources from contamination, } \\
\text { locations having impermeable soils provide a more suitable condition for landfill } \\
\text { construction. Soil textures such as clay and silt clay are the best alternatives for the } \\
\text { locations of landfill due to their low permeability. However, soil properties such as } \\
\text { soil composition, hydraulic conductivity, and permeability are contributing factors in } \\
\text { transporting contaminants into groundwater. They are therefore key elements that } \\
\text { need to be considered for landfill site selection }\end{array}$ \\
\hline Geological formations and their structural features & $\begin{array}{l}\text { Compact geological formations (without discontinuities) like igneous, metamorphic, } \\
\text { and sedimentary rocks have low permeabilities (hydraulic conductivities). Therefore, } \\
\text { these formations are the most suitable for landfill site selection }\end{array}$ \\
\hline Distance from surface water resources & $\begin{array}{l}\text { Contamination of groundwater resources is one of the major concerns of landfill site } \\
\text { selection for MSW. According to the IDOE regulations for the purpose of MSW landfill } \\
\text { site selection, a minimum distance of } 1000 \mathrm{~m} \text { from surface water (lakes and rivers) } \\
\text { must be considered as the suitable distance }\end{array}$ \\
\hline Distance from the coast & $\begin{array}{l}\text { Coastal areas are regions along which groundwater level is at or near the land surface; } \\
\text { also their population density is high. Therefore, distance from coastal regions should } \\
\text { be included in landfill site selection studies. According to the IDOE regulations, land- } \\
\text { fills must have a minimum distance of } 1000 \mathrm{~m} \text { from coastal area }\end{array}$ \\
\hline Groundwater depth & $\begin{array}{l}\text { Afzali et al. [31] in Khomeinishahr of Isfahan Province considered the depth of more } \\
\text { than } 10 \mathrm{~m} \text { vertical distance above the water table as the suitable depth for landfill } \\
\text { site selection. Considering the fact that in SaharKhiz Region, depth of groundwater } \\
\text { table is close to the surface, so for the sake of aquifer vulnerability, a depth of more } \\
\text { than } 10 \mathrm{~m} \text { was selected as the optimal depth }\end{array}$ \\
\hline Distance from protected areas and wetlands & $\begin{array}{l}\text { Protected areas are sections that have ecological value in terms of protection. These } \\
\text { areas are selected to preserve, rehabilitate, and restore the life of plants and animals } \\
\text { which have values regarding the biodiversity and genetic diversity. Therefore, } \\
\text { according to the IDOE regulations, landfills at a distance of less than } 1000 \mathrm{~m} \text { from } \\
\text { protected areas are not allowed }\end{array}$ \\
\hline
\end{tabular}

logic and Fuzzy logic approach can be mentioned as being discrete and continuous structures, respectively. Figure 3 shows the final map resulted from Boolean logic, and Fig. 4 shows result from Fuzzy standardization of ecological and socioeconomic sub-criteria for MSW landfill site selection in SaharKhiz Region. Table 6 presents final weights and priorities assigned to the ecological and socioeconomic factors using the AHP method for MSW landfill site selection. In this study, the rate of inconsistency was calculated to be 0.05 in the Expert Choice software environment for ecological and socioeconomic parameters; therefore, judgment consistency was acceptable and weighting was conducted correctly by experts. Table 7 presents the result of different classes for landfill site selection using Boolean logic. Table 8 shows the result of different classes for landfill site selection using Fuzzy logic based on WLC.

\section{Conclusions}

In this study, Boolean logic and Fuzzy logic approaches based on WLC were used to select MSW landfill sites in accordance with IDOE regulations. If the ecological and socioeconomic parameters of SaharKhiz Region, such as distance from areas with soil liquefaction, land ownership, 
Table 5 List and description of socioeconomic criteria for landfill site selection [29-33]

\begin{tabular}{lc}
\hline Socioeconomic criterion & Description \\
\hline Distance from population centers & $\begin{array}{c}\text { Locating a landfill near residential areas can cause negative environmental impacts including } \\
\text { odor, noise caused by vehicles and mechanical equipment, traffic, and dust. According to IDOE } \\
\text { regulations, landfills at a distance of less than } 1000 \mathrm{~m} \text { from population centers are not allowed } \\
\text { In studies addressing landfill site selection, barren areas and pastures with very low plant density } \\
\text { are suitable for landfill site selection; in turn, forests, rangelands, farmland, and residential areas } \\
\text { are the least suitability for landfill }\end{array}$ \\
$\begin{array}{l}\text { Since industrial and mining activities in the vicinity of the landfills increase risks of soil ero- } \\
\text { Distance from industries and gas pipeline } \\
\text { sion and sedimentation, and as leachate percolation to the surface water and groundwater } \\
\text { resources may lead to water pollution, landfills at a distance of less than 1000 m from industrial } \\
\text { areas are not allowed } \\
\text { In order to prevent damage to power transmission lines, landfills at a distance of less than } \\
\text { 1000 m from transmission lines are not allowed } \\
\text { Along with MSW landfill site selection process, availability of the access roads to the most impor- } \\
\text { tant substructures of MSW landfill site selection must be taken into consideration. Moreover, } \\
\text { landfill site should not be far from the access roads since this results in higher road construc- } \\
\text { tion cost. Based on the IDOE regulations, a 300 m distance from the access roads for MSW } \\
\text { landfill site selection will be considered suitable }\end{array}$ \\
\hline
\end{tabular}

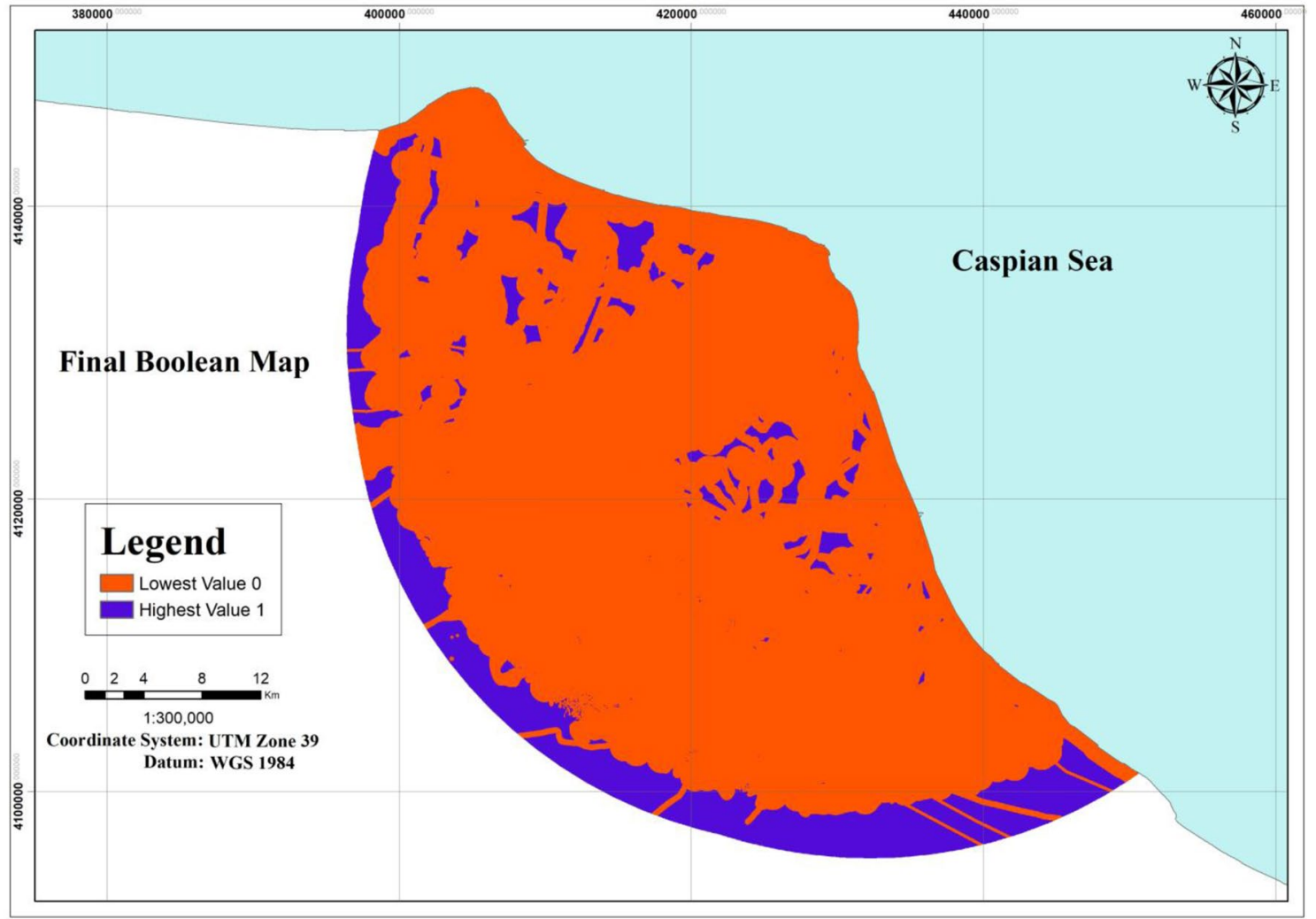

Fig. 3 Final map resulted from Boolean logic

future land use, groundwater vulnerability, and meteorological factors, such as rainfall, are used to determine landfill suitability and assessment, results will have high accuracy. In this study, comparison of Boolean logic and Fuzzy logic approaches, based on WLC, was employed to locate MSW landfill sites. Fuzzy logic allows standardization of ecological and socioeconomic sub-criteria in a continuous structure, and due to the wide range of suitability classification (between zero and one), experts' ability for the selection of the most appropriate place 


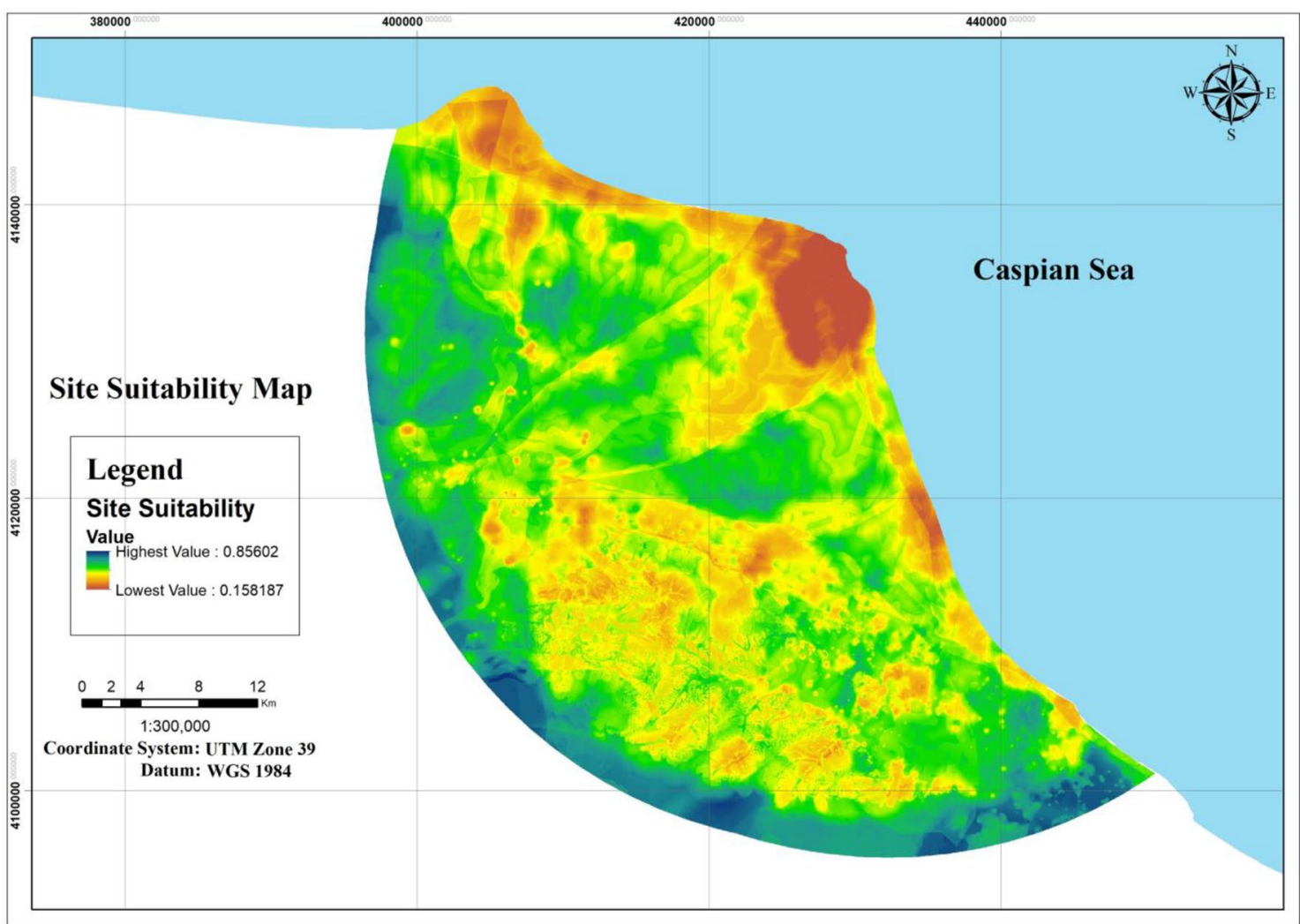

Fig. 4 Final map resulted from Fuzzy logic based on WLC

Table 6 Final weights and priorities assigned to the ecological and socioeconomic factors using AHP method

\begin{tabular}{ll}
\hline Ecological and socioeconomic factors & Weight \\
\hline Groundwater depth & 0.135 \\
Distance from lake & 0.089 \\
Soil texture & 0.085 \\
Distance from protected areas & 0.082 \\
Geological formations and their structural features & 0.076 \\
Distance from wetland & 0.070 \\
Distance from population centers & 0.068 \\
Distance from river & 0.067 \\
Slope & 0.063 \\
Distance from coastal areas & 0.056 \\
Flooding & 0.046 \\
Land use & 0.043 \\
Distance from industries & 0.031 \\
Distance from access roads & 0.030 \\
Distance from fault & 0.026 \\
Distance from gas pipeline & 0.018 \\
Distance from power transmission line & 0.016 \\
Total & 1 \\
\hline
\end{tabular}

Table 7 The result of different classes for landfill site selection using Boolean logic

\begin{tabular}{lcc}
\hline Class of suitability & Area $\left(\mathrm{km}^{2}\right)$ & $\begin{array}{c}\text { Percentage } \\
\text { of area }(\%)\end{array}$ \\
\hline Suitable & 239.53 & 14.72 \\
Unsuitable & 1387.57 & 85.28 \\
Sum of suitability & 1627.10 & 100.00 \\
\hline
\end{tabular}

Table 8 The result of different classes for landfill site selection using Fuzzy logic based on WLC

\begin{tabular}{lcc}
\hline Class of suitability & Area $\left(\mathrm{Km}^{2}\right)$ & $\begin{array}{l}\text { Percentage } \\
\text { of area }(\%)\end{array}$ \\
\hline Very high & 256.65 & 15.77 \\
High & 466.23 & 28.65 \\
Moderate & 573.20 & 35.23 \\
Low & 281.73 & 17.31 \\
Very low & 47.83 & 2.94 \\
Sum of suitability & 1627.10 & 100.00 \\
\hline
\end{tabular}


for MSW plays a more important role than the Boolean logic. In fact, results from landfill site selection, using this method, have more compatibility with the environmental capacity of SaharKhiz Region (ecological and socioeconomic capacity). Given the ecological sensitivity of the aquifers in the north of Iran, it is recommended that in future research, both the soil textures types and geological formations permeability should be taken into account for MSW landfill site selection. To increase the accuracy of assessment, 1:10,000 scale maps should be produced. This study also recommends taking into account the rules and regulations of the Environmental Protection Agency (EPA) for MSW landfill site selection. In order to provide more accurate results based on ecological and socioeconomic parameters, it is suggested that the Technique for Order Preference by Similarity to Ideal Solution (TOPSIS) method be used. Its results can be compared with results obtained from Boolean logic and Fuzzy logic based on WLC.

Acknowledgements We would like to express our thanks from Dr. Reza Samadi at energy efficiency organization of Iran for his great consultation in this project.

\section{Compliance with ethical standards}

Conflict of interest On behalf of all authors, the corresponding author states that there is no conflict of interest and no funding for this project.

Ethical approval Data gathered during questionnaires were anonymized.

\section{References}

1. Kumar S, Izhar Hassan M (2013) Selection of a landfill site for solid waste management: an application of AHP and spatial analyst tool. J Indian Soc Remote Sens 41:45-56. https://doi. org/10.1007/s12524-011-0161-8

2. Wang Y, Li J, An D, Xi B, Tang J, Wang Y, Yang Y (2018) Site selection for municipal solid waste landfill considering environmental health risks. Resour Conserv Recycl 138:40-46. https://doi. org/10.1016/j.resconrec.2018.07.008

3. Kharat MG, Kamble SJ, Raut RD, Kamble SS, Dhume SM (2016) Modeling landfill site selection using an integrated fuzzy MCDM approach. Model Earth Syst Environ 2:1-16. https://doi. org/10.1007/s40808-016-0106-x

4. Demesouka OE, Vavatsikos AP, Anagnostopoulos KP (2013) Suitability analysis for siting MSW landfills and its multicriteria spatial decision support system: method, implementation and case study. Waste Manag 33:1190-1206. https://doi.org/10.1016/j. wasman.2013.01.030

5. Nazari A, Salarirad MM, Aghajani Bazzazi A (2012) Landfill Site Selection by decision-making tools based on Fuzzy multi-attribute decision-making method. Environ Earth Sci 65:1631-1642. https://doi.org/10.1007/s12665-011-1137-2

6. Hamzeh M, Abbaspour RA, Davalou R (2015) Raster-based outranking method: a new approach for municipal solid waste landfill (MSW) siting. Environ Sci Pollut Res 22:12511-12524. https://doi.org/10.1007/s11356-015-4485-8

7. Kara C, Doratli N (2012) Application of GIS/AHP in siting sanitary landfill: a case study in Northern Cyprus. Waste Manag Res 30:966-980. https://doi.org/10.1177/0734242X12453975

8. Ersoy $H$, Bulut $F$ (2009) Spatial and multi-criteria decision analysis-based methodology for landfill site selection in growing urban regions. Waste Manag Res 27:489-500. https://doi. org/10.1177/0734242X08098430

9. Gorsevski PV, Donevska KR, Mitrovski CD, Frizado JP (2012) Integrating multi-criteria evaluation techniques with geographic information systems for landfill site selection: a case study using ordered weighted average. Waste Manag 32:287-296. https:// doi.org/10.1016/j.wasman.2011.09.023

10. Eskandari M, Homaee M, Falamaki A (2016) Landfill site selection for municipal solid waste in mountainous areas with landslide susceptibility. Environ Sci Pollut Res 23:12423-12434. https:// doi.org/10.1007/s11356-016-6459-x

11. Demesouka OE, Vavatsikos AP, Anagnostopoulos KP (2014) GIS-based multi-criteria municipal solid waste landfill suitability analysis: a review of the methodologies performed and criteria implemented. Waste Manag Res 32:270-296. https://doi. org/10.1177/0734242X14526632

12. Osra FA, Kajjumba GW (2019) Landfill site selection in Makkah using geographic information system and analytical hierarchy process. Waste Manag Res. https://doi.org/10.1177/0734242X19 833153

13. Yildirim U, Guler C (2016) Identification of suitable future municipal solid waste disposal sites for the Metropolitan Mersin (SE Turkey) using AHP and GIS techniques. Environ Earth Sci 75:101117. https://doi.org/10.1007/s12665-015-4948-8

14. Torabi-Kaveh $M$, Babazadeh $R$, Mohammadi SD, Zaresefat $M$ (2016) Landfill site selection using combination of GIS and fuzzy AHP, a case study: Iranshahr, Iran. Waste Manag Res 34:438-448. https://doi.org/10.1177/0734242X16633777

15. Karimzadeh Motlagh Z, Sayadi MH (2015) Siting MSW landfills using MCE methodology in GIS environment (case study: Birjand plain, Iran). Waste Manag 46:322-337. https://doi.org/10.1016/j. wasman.2015.08.013

16. Abd-El Monsef H (2015) Optimization of municipal landfill siting in the Red Sea Coastal desert using geographic information system, remote sensing and an analytical hierarchy process. Environ Earth Sci 74:2283-2296. https://doi.org/10.1007/s1266 5-015-4220-2

17. Ghobadi MH, Babazadeh R, Bagheri V (2013) Siting MSW landfills by combining AHP with GIS in Hamedan Province, Western Iran. Environ Earth Sci 70:1823-1840. https://doi.org/10.1007/s1266 5-013-2271-9

18. NPPD (2012) Site survey for nuclear power plants in the Sahar Khiz Area, 4th edn. NPP Develop Comp, Tehran, pp 150-153

19. Iran's Department Of Environment (IDOE) (2009) Office for soil and water pollution studies. Guidelines for siting MSW sanitary landfill, Tehran, Iran in Persian

20. Moeinaddini M, Khorasani N, Danehkar A, Darvishsefat AA, Zienalyan M (2010) Siting MSW landfill using weighted linear combination and analytical hierarchy process (AHP) methodology in GIS environment (case study: Karaj). Waste Manag 30:912-920. https://doi.org/10.1016/j.wasman.2010.01.015

21. Sharifi M, Haddi M, Vessali E, Mosstafakhani P, Taheri K, Shahoie S, Khodamoradpour M (2009) Integrating multi-criteria decision analysis for a GIS-based hazardous waste landfill siting in Kurdistan Province, Western Iran. Waste Manag 29:2740-2758. https ://doi.org/10.1016/j.wasman.2009.04.010

22. Saaty TL (1980) The analytical hierarchy process, planning, priority setting, resource allocation (decision making serious), 1st edn. McGraw-Hill, New York, pp 154-155 
23. Pasalari $\mathrm{H}$, Nabizadeh Nodehi R, Mahvi AH, Yaghmaeian K, Charrahi Z (2019) Landfill site selection using a hybrid system of AHP-Fuzzy in GIS environment: a case study in Shiraz city, Iran. MethodsX 6:1454-1466

24. Kamdar I, Ali S, Bennui A, Techato K, Jutidamrongphan W (2019) Municipal solid waste landfill siting using an integrated GIS-AHP approach: a case study from Songkhla, Thailand. Resour Conserv Recycl 149:220-235

25. Malczewski J, Rinner C (2015) Multi-criteria decision analysis in geographic information sciences, 1st edn. Springer, New York, pp 220-228

26. Pinar Yal G, Akgun H (2014) Landfill site selection utilizing TOPSIS methodology and clay liner geotechnical characterization: a case study for Ankara, Turkey. Bull Eng Geol Environ 73:369-388. https://doi.org/10.1007/s10064-013-0562-8

27. De Feo G, De Gisi S (2014) Using MCDA and GIS for hazardous waste landfill siting considering land scarcity for waste disposal. Waste Manag 34:2225-2238. https://doi.org/10.1016/j.wasma n.2014.05.028

28. Donevska KR, Gorsevski PV, Javanovski M, Pesevski I (2012) Regional non-hazardous landfill site selection by integrating Fuzzy logic, AHP and geographic information systems. Environ Earth Sci 67:121-131. https://doi.org/10.1007/s1266 5-011-1485-y

29. Isalou AA, Zamani V, Shahmoradi B, Alizadeh H (2013) Landfill site selection using integrated fuzzy logic and analytic network process (F-ANP). Environ Earth Sci 68:1745-1755. https://doi. org/10.1007/s12665-012-1865-y

30. El-Baba M, Kayastha P, De Smedt F (2014) Landfill Site selection using multi-criteria evaluation in the GIS interface: a case study from the Gaza Strip, Palestine. Arab J Geosci 8:7499-7513. https ://doi.org/10.1007/s12517-014-1736-9

31. Afzali A, Sabri S, Rashid M, Samani JM, Ludin A (2014) Intermunicipal landfill site selection using analytic network process. Water Resour Manage 28:2179-2194. https://doi.org/10.1007/ s11269-014-0605-3

32. Eskandari M, Homaee M, Mahmoodi S, Pazira E, Genuchten MTV (2015) Optimizing landfill site selection by using land classification maps. Environ Sci Pollut Res 22:7754-7765. https://doi. org/10.1007/s11356-015-4182-7

33. Arkoc O (2014) Municipal solid waste landfill site selection using geographical information system: a case study from Corlu, Turkey. Arab J Geosci 7:4975-4985. https://doi.org/10.1007/s1251 7-013-1107-y

Publisher's Note Springer Nature remains neutral with regard to jurisdictional claims in published maps and institutional affiliations. 